\title{
As tropas de ordenanças na Ilha de Santa Catarina durante os setecentos
}

\author{
The ordenanças of troops on the Island of Santa Catarina during the seven hundred
}

Jeferson dos Santos Mendes*

\author{
Palavras-chave: \\ Ordenanças \\ Ilha de Santa Catarina \\ Soldado-cidadão
}

Keywords:

Ordenanças

Santa Catarina Island

Citizen-soldier

\begin{abstract}
Resumo: O presente trabalho, de forma introdutória, busca analisar as tropas de ordenanças na Ilha de Santa Catarina. As condições desses regimentos relatados pelos viajantes europeus de passagem pela Ilha durante os séculos XVIII e XIX, além das nomeações realizadas pelos governadores e as dificuldades de organizar um corpo militar. Por outro lado, muito rapidamente vamos tratar da importância da Ilha de Santa Catarina no contexto do século XVIII e suas funções estratégicas e militares na geopolítica colonial.
\end{abstract}

\begin{abstract}
The present work, in an introductory form, seeks to analyze the troops of ordenanças on the Island of Santa Catarina. The conditions of these regiments reported by European travelers passing through the Island during the eighteenth and nineteenth centuries, besides the appointments made by the governors and the difficulties of organizing a military body. On the other hand, very soon we will consider the importance of the island of Santa Catarina in the context of the eighteenth century and its strategic and military functions in colonial geopolitics.
\end{abstract}

Recebido em $1^{\circ}$ de junho de 2018. Aprovado em 27 de agosto de 2018.

\section{A Ilha}

Situada a meio caminho entre o Rio de Janeiro e o Rio da Prata, a Ilha de Santa Catarina foi parada obrigatória de viajantes europeus a partir do século XVI. A grande maioria das embarcações europeias, além de explorar a Ilha, buscava um porto privilegiado para se refazer de aprovisionamentos, água, víveres e alimentos frescos. A atracagem favorecia as viagens de ida e volta à embocadura do Rio da Prata, destino de grande parte das embarcações europeias no extremo sul da América ${ }^{1}$.

A descoberta do ouro nos sertões mineiro e paulista forçou o governo luso-brasileiro à expansão e à consolidação colonial rumo à América Meridional e ao Rio da Prata. Em 1651, Francisco Dias Velho Monteiro partiu de Santos com a família e um número considerável de índios e escravos para se estabelecer na localidade que deu início à vila do
Desterro. Vinte e nove anos depois, Dom Manuel Lobo, então governador da Capitania do Rio de Janeiro, chefiando uma pequena expedição partiu em direção ao estuário do Rio da Prata. A fundação da Colônia do Sacramento (1680), em frente a Buenos Aires, estabelecia o domínio comercial sobre o Rio da Prata e uma tentativa de apropriação e alargamento do território, além de que, com a possessão, a Coroa Portuguesa manteria uma conexão com Potosi, favorecendo oalinhamento com os ingleses e o contrabando na região (TEJERINA, 2004 , p. 94). O comércio e o roubo imiscuíam-se e serpenteavam no vasto território da América Meridional, tendo como grande articulador o Rio da Prata $^{2}$. Entretanto, a ação lusitana confrontava com a expansão espanhola no mesmo espaço. Gradativamente, as forças hispânicas das missões jesuíticas avançavam ao Paraguai, para leste dos rios Paraná e Uruguai e demais províncias adjacentes

\footnotetext{
* Doutorando em História e Cultura do Brasil pela Faculdade de Letras da Universidade de Lisboa. Professor da Universidade de Passo Fundo (UPF). E-mail: mendesjeferson@campus.ul.pt.
} 
ao Rio da Prata. A Ilha, nesse imbróglio, ganhou relevância e importância estratégica de manutenção e apropriação do território.

É certo que, desde a segunda metade do século XVII, a Ilha de Santa Catarina foi um espaço destinado ao desterro. Lugar de criminosos e vagabundos desonestos. Marlon Salomon lembra que até a década de 1730, a Ilha de Santa Catarina e a Colônia do Sacramento foram lugares de degredo: "A Ilha, afastada do continente e isolada pelas águas do mar que a vigiam, assume a função punitiva de afastar e isolar aqueles que comprometem a ordem na sociedade" (SALOMON, 2004, p. 80). Vale lembrar que, a grande maioria dos soldados, eram ex-degredados, presos, que na maioria das vezes, eram enviados ou para Angola ou para a Ilha de Santa Catarina. Matheus Homem da Costa acusado de ter aberto o saco de correspondência do governador de Minas, por exemplo, recebeu a pena de "quatro anos de degredo para a Ilha de Santa Catarina" (CARTA DO VICE-REI, 1962, p. 167-170). Com o tempo a Ilha deixou de ser vista como um lugar apropriado ao degredo. Como destaca Seidler (1996, p. 280), ao aportar na Ilha de Santa Catarina no início do século XIX, "[...] outrora esse jardim era lugar de desterro de criminosos portugueses, de ande o nome da capital; realmente por esse preço era-se tentado a praticar algum crime para também ser desterrado, pois era ceder um instante ao inferno em troca do resto da vida no céu".

Durante os séculos que precederam a chegada dos primeiros europeus, muitos viajantes produziram relatos de suas viagens. A Ilha foi descrita, na maioria das vezes, como de solo fértil e excelente para o plantio.

A terra de Santa Catarina é muito fértil, e produz quase que por si mesmo variadas espécies de frutos. Está coberta de uma floresta de árvores sempre verdes, que, pela fertilidade do solo, são de tal maneira entremeadas de sarças, espinheiros e arbustos, que o todo forma um conjunto impossível de atravessar, a menos que se tome algum caminho que os habitantes fizeram para sua comodidade. Estes caminhos, e algumas terras situadas ao longo da margem continental, que nós desbravamos para se fazer plantações, são os únicos lugares da ilha que não estão cobertos de árvores. (ANSON, 1996, p. 64).

Vários aventureiros e viajantes buscavam na Ilha "[...] um sítio apropriado para fazer aguada e as habitações dos portugueses, a fim de conseguir alguns refrescos" (FRÉZIER, 1996, p. 19). Entretanto, havia dificuldades de manutenção. Como lembra Braudel, “[...] nenhuma ilha está segura do dia de amanhã, e todas estão condenadas a viver dos seus próprios recursos, do seu solo, dos seus pomares, dos seus rebanhos ou, não o podendo de todo, a abrir-se ao exterior" (BRAUDEL, 1983, p. 175). Com relação à Ilha de Santa Catarina não foi diferente. Frézier (1996, p. 23-24) lembra a paupérrima situação que viviam os citadinos:

$\mathrm{Na}$ verdade, encontram-se eles em tão grande carência de todas as comodidades da vida que, em troca dos víveres que traziam a nós não aceitavam dinheiro, dando mais importância a um pedaço de pano ou fazenda para se cobrir, protegendo-os das penúrias do tempo; satisfazem-se com o vestuário de uma camisa e um par de calças; os mais distintos usam também um paletó de cor e um chapéu: quase ninguém usa meias ou sapatos, sendo obrigados, no entanto, a cobrir as pernas quando entram no mato utilizando-se, então, da pele da perna de um tigre como perneira. Não são mais exigentes com a alimentação do que com o vestuário; um pouco de milho, batatas, alguns frutos, peixe e caça, quase sempre o macaco, os satisfazem. Esta gente, à primeira vista, parece miserável, mas eles são efetivamente mais felizes que os europeus [...] vivem na ignorância; são cristãos, é verdade, mas como podem ser instruídos em sua religião não havendo senão um vigário na Lagoa que lhes vem rezar a missa somente nas principais festas do ano: pagam, no entanto, o dízimo à Igreja, que é a única coisa que deles exigem.

O caldeamento populacional europeu, ameríndio e africano foi transformando as populações da América do Sul. Nesse sentido, 
referindo-se à Ilha, Pernetty (1996, p. 82) observou: "veem-se na Ilha de Santa Catarina homens de todo o tipo de pele, do negro até o branco. Os mulatos são em maior número, geralmente feios, com um ar selvagem, como se fossem uma mistura de brasileiros com negros". O viajante ainda descreve os habitantes:

Andam descalços, cabeça descoberta e muito mal penteados; suas roupas consistem em uma camisa, uma calça e às vezes um casaco que jogam nas costas, à maneira dos espanhóis. Os que ganham mais, utilizam um chapéu de forma muito alta, com abas de quase dez polegadas abaixadas. Estes estão cobertos e usam um paletó, acrescido de um casaco amplo que vai até aos pés, levantando às vezes a ponta de baixo para o ombro do lado oposto. Ao invés do chapéu, alguns usam um capuz do mesmo tecido do casaco, onde está preso e serve para cobrir a cabeça, costume este que impede mesmo a seus amigos de serem reconhecidos. (PERNETTY, 1996, p. 82).

Quanto aos oficiais e autoridades coloniais, vestiam-se com uma "mortalha", a mesma vestimenta dos franceses. Os escravos, à maneira das outras capitanias:

[...] andam quase nus; a maioria se cobre com uma tanga em torno dos ombros. É raro encontrar algum deles com uma camisa ou veste. Mas, desde que recebam sua liberdade, eles podem se vestir como os brancos. As escravas negras usam somente um pedaço de tecido que as cobre da cintura até acima do joelho; as que estão libertas se vestem como as outras mulheres, com uma saia e uma camisa abotoada na frente, como as camisas dos homens, e, quando saem de casa, colocam um grande pano por cima, de um tecido fino de lã, muitas vezes branco, bordado com um fio de ouro, prata ou outro material, segundo suas condições e possibilidades. Esta peça de tecido tem, em geral, duas almas de comprimento por uma de largura. É arrumada de maneira que um dos ângulos se encontre no meio das costas e produza um efeito semelhante ao do capuz usado pelos carmelitas. O ângulo oposto cobre a cabeça, os dois restantes, depois de cobrirem os ombros e os braços até ao cotovelo, vem se cruzar no peito, à moda dos manteletes das francesas. Às vezes, também, ao invés de cruzarem no peito, estas pontas passam sob o braço, que já está coberto, deixando ver a gargantilha. Esta maneira de se vestir é muito incômoda porque, ao menor movimento do corpo, o tecido perturba (PERNETTY, 1996, p. 82-83).

A 26 de março de 1726, foi criada a vila do Desterro. Contudo, como lembra Prado Jr. (1953, p. 84), "[...] não havia aí mais que uma população escassa e constituída em sua quase totalidade pelas guarnições militares que defendiam as fronteiras da colônia". Quanto à Ilha de Santa Catarina, durante quase três séculos, a densidade demográfica da Ilha pouco se alterou?: índios silvícolas, autoridades coloniais e militares, fugitivos, escravos se imiscuíam entre as elites locais. A assimétrica relação de poder, o caldeamento populacional provocava sisudas querelas entre índios autóctones e europeus. A população local, insegura, fugia para os bosques, as montanhas e os sítios mais seguros, longe dos nativos. Sem fortalezas, sem um corpo militar permanente, a população vivia entre a beleza natural da Ilha e o medo iminente da floresta.

Em março de 1735, aportava no Rio de Janeiro, o brigadeiro José da Silva Pais. Tinha a incumbência de sucessor imediato de Gomes Freire de Andrada, no governo do Rio de Janeiro, em sua ausência. A 9 de junho de 1736, Gomes Freire passou uma série de instruções ao brigadeiro. Entre elas: tomar posse do território do Rio Grande, ocupando e fortificando a região; defender a Colônia do Sacramento dos constantes assédios espanhóis, sobre cerco desde outubro de 1735 a setembro de $1737^{4}$; além da tomada de Montevidéu e fundar uma fortificação em Maldonado. Entretanto, a falta de água e madeira impossibilitou qualquer fundação, restando como única alternativa fortificar o Rio Grande de São Pedro, com o presídio Jesus-Maria-José, em princípio de 1737 (POSSAMAI, 2004, p. 170).

Um ano depois, a coroa transferia a jurisdição da Ilha de Santa Catarina, Rio Grande 
de São Pedro e Laguna (1742) da Capitania de São Paulo para o Rio de Janeiro. A partir daí, com mais frequência, a Ilha passava a constar em ofícios e missivas das autoridades coloniais e lisboetas. A conservação do território entrava na ordem do dia da Coroa Portuguesa. José da Silva Pais foi nomeado governador. A ele foram oneradas as bases defensivas e organizativas. Durante o comando, três fortalezas foram erguidas na Barra Norte e uma na Barra Sul (SILVA, 2008, p. 56). Para Walter Piazza, a principal explicação para a fundação da Capitania da Ilha de Santa Catarina foi de "ordem política" (PIAZZA, 1983, p. 123).

Por outro lado, vale reforçar que a Ilha está localizada no centro do Rio de Janeiro com a Colônia do Sacramento, mantendo a ligação do extremo norte do Brasil com o extremo sul. É capaz de receber embarcações de todas as capitanias, desde a Bahia, Minas e São Paulo até o Rio Grande e Colônia do Sacramento. Enquanto os castelhanos movimentavam seus exércitos em direção ao oeste do rio Uruguai, os portugueses tentavam reforçar os territórios ainda virgens de assaltos e cerco. A Ilha era um desses territórios, por estar localizada na região meridional. Por essa razão, passou a constar nos relatórios dos estrategistas castelhanos um ataque ou sua ocupação.

Em 1748 iniciou-se o processo de povoamento da Ilha. Com imigrantes vindos das ilhas oceânicas e continental, nomeadamente: ilhas dos Açores, madeira e região do Minho, em território português. Em oito anos, mais de seis mil pessoas migraram para a Ilha de Santa Catarina. Com os imigrantes açorianos e madeirenses formaram-se diversas povoações e freguesias. E, com eles, organizou os corpos de ordenanças, responsáveis pela defesa da Ilha. É certo que, “[...] a política de colonização com imigrantes vindos das ilhas de Açores e Madeira faz parte desse contexto da territorialização militar" (MARTINELLO, 2016, p. 90). Dessa forma, as condições dessas tropas relatadas pelos viajantes europeus em passagem pela Ilha nos séculos XVIII e XIX, as nomeações realizadas pelos governadores e a dificuldade de organização militar será o objeto de atenção da nossa análise.

\section{A companhia de ordenanças: 0 "soldado-cidadão"}

No alvorecer do século XIX, René Lesson, viajante francês, percebeu na Ilha de Santa Catarina um militar diferenciado. Constatou que os soldados de milícia eram engajados nos corpos do exército somente durante períodos de guerra. Em tempos de paz, mantinham-se na labuta em suas terras. Essas particularidades, diferenciadas, levou o viajante francês a defini-los como "soldados-cidadãos". Caracterizou-os:

\begin{abstract}
Entre os habitantes encontramse homens robustos e bonitos; os bigodes que parte deles usa, indica que pertencem à milícia das costas, e que ao primeiro sinal devem se render às baterias em defesa do território da província. Estes soldados-cidadãos cultivam ao redor de suas moradias, hortas que fornecem o sustento a suas famílias. Criam alguns animais de terreiro, e galinheiros como aves domésticas, que eles vendem aos navios que passam, em troca de algum lucro, que compense pela falta de regularidade com que o governo lhes paga o soldo. (LESSON, 1996, p. 268).
\end{abstract}

É importante lembrar que, a utilização da população civil na organização das forças militares na América portuguesa foi uma prática comum durante o período colonial. Aos colonos foram dadas obrigatoriedades de zelar pela segurança das capitanias (IZECKSOHN, 2014, p. 487). Em 1548, ao procurar estabelecer a conquista e o controle dos domínios ultramarinos, a Coroa Portuguesa expediu, juntamente com o governador-geral Tomé de Souza, um regimento. O governador, com soldados, artilharia e demais instrumentos bélicos, responsabilizava-se pela fortificação das barras e portos para melhor escoamento do comércio marítimo (PUNTONI, 2004, p. 43).

Nesse primeiro momento, cabia aos donatários das capitanias a defesa, a otimização do espaço colonial e, principalmente, de municiar a população. O alvará das armas de 1569 tornou obrigatório a todos os homens livres a posse de 
armas, fossem elas de fogo ou brancas. Logo em seguida, a coroa regulamentou na colônia o serviço das ordenanças. Formada pelo engajamento coercitivo de todos os moradores de um termo ${ }^{5} \mathrm{com}$ idade entre 18 e 60 anos, com exceção de eclesiásticos e fidalgos ${ }^{6}$. Como aponta Jorge Couto, na clássica obra A construção do Brasil, ao governador-geral foram designados amplos poderes.

$\mathrm{Na}$ esfera de defesa, o regimento fixava o armamento mínimo que deveria existir em cada capitania donatária, engenho ou fazenda; obrigava todos os moradores que possuíssem casas, terras ou navios a ter, pelo menos, besta, espingarda, lança ou chuça; ordenava a fortificação de todas as vilas e povoações e impunha aos senhores de engenho ou fazenda a edificação de estruturas defensivas (torres ou casas-fortes) nas suas propriedades. (COUTO, 1998, p. 233).

Por outro lado, a organização militar no Brasil colonial estava basicamente estruturada em três grandes escalões: tropas de linha, auxiliares e tropas de ordenanças. A tropa de linha caracterizava-se por ser paga, nobre e profissional. Geralmente composta de regimentos portugueses: Bragança, Moura e Estremoz. Já as tropas de ordenanças e auxiliares não eram remuneradas. Eram compostas, a grande maioria, de moradores, agricultores "que, quando se fazia mister, deixavam suas lidas para acudir as necessidades militares" (MELLO, 2009, p. 241).

Sobre a Ilha de Santa Catarina, no início do século XVIII, o engajamento das tropas de ordenanças - cujas principais origens de São Vicente - eram pouco expressivas. Por outro lado, as condições econômicas e sociais eram degradantes. Em 1712, o engenheiro militar francês Amédée Frézier ancorou na Ilha e notou que a situação dos soldados responsáveis pela defesa e segurança era degradante e paupérrima, uma vez que as armas de defesa eram insuficientes e estavam em péssimo estado. Frézier chamou a atenção para as condições bélicas: "suas armas comuns são os facões de caça, flechas e machados; possuem poucas espingardas e raramente pólvora"' (FRÉZIER, 1996, p. 23). La Perouse, outro viajante francês, em seu diário de bordo, reafirmou a pauperidade vivida pelas tropas, "[...] a guarnição do forte principal, quando ancorámos, era de cinquenta soldados mal vestidos, e mal pagos, comandados por um capitão" (EXTRACTO, 1902, tomo LXV, primeira parte, p. 322-326), registrou ele.

Entretanto, esse mesmo efetivo militar estava inserido na dinâmica do mundo moderno. Assentado em um novo momento da história das guerras, presenciouosepultamentodamedievalidade e a aquiescência de métodos modernos de guerrear, outra racionalidade militar incorporada à otimização dos exércitos e suas funcionalidades. Durante a consolidação da "[...] era das armas de fogo, o uso dos mosquetões (armamento de um tiro que precisava ser carregados), exigia a operação de complexa coreografia de salvas repetidas dadas por fileiras de atiradores em pé, de cócoras ou deitados" (CARNEIRO, 2011, p. 181).

O mesmoviajantelembrou que os moradores não tinham responsabilidades tributárias com o governo português, mas eram súditos e obedeciam aos comandantes nomeados. Serviam em caso de hostilidades interna ou externa "[...] contra os inimigos da Europa e os índios do Brasil, com os quais andam quase sempre em guerra". (FRÉZIER, 1996, p. 23). O receio dos habitantes autóctones fazia com que só penetrassem na densa mata continental em grupos de 30 ou 40 homens juntos e bem armados.

O edital publicado na ilha dos Açores e da Madeira não era claro quanto ao serviço militar. Em geral, os migrantes ficariam isentos de servir nas Tropas pagas, mas o mesmo não acontecia nas ordenanças. A provisão régia de 8 de agosto de 1747, determinou ao governador José da Silva Pais a criação de um corpo de ordenanças em cada localidade fundada, conforme demonstra o seguinte trecho:

Em cada lugar dos sobreditos fareis logo levantar uma Companhia de Ordenanças, nomeando-lhe oficiais no caso que não vão de cá nomeados alguns Capitães, e nestas Companhias se alistarão todos os moradores casados, e solteiros, e dareis as ordens para a sua disciplina na mesma forma que se pratica nas outras terras do vosso Governo. (BRITO, 1829, p. 176). 
Por outro lado, as companhias de ordenanças da Ilha de Santa Catarina eram corpos heterogêneos, compostos, na sua maioria, de açorianos e madeirenses. Uma força, solidificada e contemporizada no Antigo Regime. A condição da Ilha exigia um soldado ambivalente, capaz de aglutinar diferentes tarefas, acoplado ao mundo rural e à penosa vida militar, subordinada. As tropas não eram pagas, e possuíam múltiplas capacidades, visto que, além do manuseio das armas nas injunções, eram habilidosos no trato da terra. A maior parte do tempo dos soldados era dedicada para as suas atividades. Em casos de perturbações, assédios, contendas, escaramuças e guerra eram engajados no exército, nas tropas de auxiliares.

Os seis mil migrantes formavam uma amálgama crescente. Dinamizar os espaços e ampliar o número de soldados em armas estavam na ordem do dia das autoridades coloniais e lusitanas. Buscavam a solidificação do espaço defensivo; por isso, os imigrantes eram engajados nos corpos de ordenanças. O estado lusitano, as autoridades coloniais e locais da capitania oneravam aos colonos a defesa militar e o desenvolvimento econômico do território.

Por outro lado, é importante lembrar que boa parte do recrutamento foi realizada nas ilhas atlânticas. Como recorda José Damião Rodrigues (2010, p. 20): “[...] ao longo da primeira metade de Setecentos a coroa continuou a promover a saída de 'casais' ilhéus para a América do Sul com o objetivo de povoar e defender as regiões fronteiriças meridionais e setentrionais"; entretanto, passaram a adotar uma nova estratégia: "a dos recrutamentos militares nos Açores, a partir da segunda metade do século XVIII".

De forma geral, os soldados pertencentes ao regimento de ordenanças tinham um cuidado diferenciado. Militarmente, eram corpos inertes, parados, não se locomoviam como os corpos regulares e de primeira linha. Como lembra Izecksohn (2014, p. 484):

Seu treinamento consistia na prática continuada dos combates ou na experiência adquirida através do convívio familiar, isto é, com pouco adestramento profissional. Seus soldados eram frequentemente os moradores das localidades, relacionados aos comandantes por vínculos pessoais, os mesmos liames que reforçavam sua disciplina através de uma subordinação que possuía pouco em comum com as regras hierárquicas de uma organização total moderna. A experiência militar, portanto, foi muito pouco homogênea [...]. Nessas condições, a estrutura tendeu a seguir e confirmar as hierarquias locais, com algumas brechas para indivíduos procedentes de grupos subalternos que se destacassem nos combates ou na arregimentação das tropas.

Antes do processo de povoamento da Ilha por açorianos e madeirenses, pouco ou quase nada se falou em organizar uma companhia de ordenanças. Segundo Oswaldo de Cabral (1972, p. 89), “[...] não teria sido mesmo possível organizar qualquer corpo militar desse tipo, como de qualquer outro, pois o contingente populacional era reduzidíssimo". O desprezo refletia a inabilidade política. Contudo, com a criação da vila da Laguna e a instabilidade no estuário do Rio da Prata, forçou-se as autoridades coloniais a empenharem esforços paliativos. Segundo Manoel Joaquim de Almeida Coelho (1856, p. 10-11), em 1720, o desembargador ouvidor geral Rafael Pires Pardinho recomendou à Câmara da Laguna "[...] que se elegesse um capitão de ordenanças, um Alferes, e dois Sargentos, ficando o povo obrigado a correr as armas logo que tocasse rebate".

A organização militar da América Meridional, aos poucos, foi tomando corpo. José da Silva Pais, argutamente reconheceu a necessidade de criar mecanismos de manutenção defensiva. E, o corpo de ordenanças, juntamente com a leva de imigrantes que aportavam na Ilha de Santa Catarina eram ótimos dispositivos. Antes mesmo de receber as primeiras levas de açorianos e madeirenses, o brigadeiro, escreveu às autoridades lisboetas, dizendo que aumentaria a "cultura daquelas terras", com os imigrantes e, principalmente, "dos filhos dos mesmos casais se recrutariam as tropas". (FLORES, 2004, p. 32).

Com o desenvolvimento dos núcleos populacionais, foram dadas novas prerrogativas 
organizacionais. Em cada localidade, foi organizado um corpo de ordenanças, a cargo de um comandante reinol, o qual tinha como principal finalidade a manutenção do território da América Meridional.

No governo do brigadeiro Manuel Escudeiro de Souza (1749-1753), foram dadas as principais medidas ocorreu o estabelecimento dos postos. Os governadores receberam o direito de nomeação. Procuravam nomes com perfis sociais, políticos e principalmente militares. Fernanda Olival, em seu já clássico estudo As ordens militares e o estado moderno: Honra, mercê e venalidade em Portugal (1641-1789) sublinha a relevância do conceito da economiada mercêcomo dispositivo de perpetuidade da produção dos serviços militares. Nesse ponto de vista, "quem somara determinado número de anos de serviços devia vê-los recompensados" (OLIVAL, 2001, p. 238). O próprio marquês do Lavradio, logo após tomar posse, fez um pedido ao conde de Oeiras de novos oficiais para os regimentos. Contudo, recomendava às autoridades, na escolha dos novos oficiais, "[...] duas coisas, a primeira que deve haver um grande cuidado em que os coronéis da Europa, não nomeiem para cá aqueles a quem lá não se acha préstimo, em segundo lugar que o meio de virem gostosamente os que lá forem bons e continuarem cá a servir com distinção", escreveu a Luís de Almeida. (CARTA DO MARQUÊS, 1962, p. 198). Dessa forma, a grande maioria dos comandantes escolhidos para servir nas companhias de ordenanças seguiam a lógica da continuidade dos serviços militares ou de fidalguia. Não por acaso, boa parte dos comandantes era responsável em sua localidade de origem - Ilha dos Açores e Madeira - possuíam alguns postos militares ou provinham da nobreza. Boa parte das nomeações ocorreu em setembro de 1753. Na Freguesia de Nossa Senhora da Conceição da Lagoa, Escudeiro nomeou o comandante Mateus Lourenço Coelho, que já era comandante na Ilha Terceira; na freguesia de São José da Terra Firme o capitão Manuel de Sousa e Silva, que já ocupava o cargo militar na Ilha Graciosa; na companhia formada no rio de Ratones, extremo norte da Ilha fora nomeado Agostinho Machado, por ser "gente nobre da Ilha Terceira" e, o mesmo requisito foi dado a Manuel Medeiros e
Souza nomeado para o Distrito de Praia Comprida, nobre da Ilha de São Miguel, e para Francisco José Leitão Rambone, Alferes da nova companhia estabelecido na vila do Desterro, que provinha de família de nobres dos Açores. (CABRAL, 1972, p. 90-91).

Assim como em outras capitanias, nas companhias de ordenanças eram empregados homens pobres e de baixa estirpe. Segundo Assis (1988, p. 58-59), muitos foram incorporados nos serviços das vilas. Sem soldos e emolumentos, além de reduzido custo para o estado, dedicavam mais tempo para roças e outras atividades. Keegan (1995, p. 22) foi peremptório ao afirmar que: "[...] todos os exércitos regulares, até mesmo os da Revolução Francesa, recrutavam soldados irregulares para patrulhar, reconhecer e travar escaramuças para eles". No que diz respeito à Ilha de Santa Catarina, a "vinculação de todos os moradores casados e solteiros" no serviço militar gratuito representava um meio eficaz de mantê-los "em ordem e disciplina" (SALOMON, 2002, p. 48).

A articulação desenvolvida na América Meridional movimentava tropas, pessoas e autoridades coloniais. Uma estrutura organicamente montada entre a Colônia do Sacramento, Rio Grande de São Pedro e Ilha de Santa Catarina. Muitos colonos, logo após aportarem na Ilha, eram enviados para o continente do Rio Grande e Sacramento; e, na grande maioria dos casos, eram engajados nas tropas de ordenanças. As autoridades coloniais, migravam de postos e de comando, sendo responsáveis pela engrenagem de um sistema defensivo e ofensivo.

Contudo, a inabilidade do sistema mantinha o afastamento populacional. Além disso, o exército era o principal destino de criminosos, devedores, fugitivos, transeuntes e, consequentemente, sedimentava a aversão dos residentes nos núcleos e, até mesmo, na capitania. A Coroa Lusitana reforçou alianças com poderes locais, mas não impediu o definhamento do sistema. A população mostravase descontente com tal instrumentalidade. Durante o governo do coronel Francisco Antônio Cardoso de Meneses (1762-1765), os moradores queixavam-se da 
[...] rigidez com que exigia trabalhassem eles não só em obras públicas como no trato das armas. Homem de tropa, frequentemente obrigava os moradores a exercícios militares, não hesitando em retirá-los do trabalho nas suas terras, não poupando sequer os próprios Vereadores da Câmara. E, se protestavam, fazia-os espancar.

Tão logo a Câmara protestou, segundo Cabral (1972, p. 91), "pedindo que se lhes abrandassem o rigor e a frequência nos exercícios". Sem perda de tempo o ministro Francisco Xavier de Mendonça Furtado escreveu uma longa justificativa à Câmara: "É indispensável que todos os moradores dela se conservem em estado de tomarem as armas com ciência, para rebater o orgulho do inimigo" (CABRAL, 1972, p. 92); além disso, recomendou às autoridades que reservassem domingos e dias santos aos exercícios. Como lembra Christiane Figueiredo Pagano de Mello (2009, p. 186), uma das grandes causas da recusa da população colonial ao serviço militar eram justamente "os maus-tratos vexatórios que recebiam de seus governantes".

No governo do marquês do Lavradio (17691778), conforme relata Mello (2009, p. 83), a Coroa Lusitana operacionalizou a utilização "da pedagogia militar para impor uma disciplina aos habitantes das colônias no Ultramar"; o principal objetivo era construir uma "força capaz de reunir, ou reduzir, todos os indivíduos a um só corpo". Entretanto, ao contrário do que buscavam as autoridades coloniais e a Coroa Portuguesa, as companhias de ordenanças formadas nas capitanias e no Reino, não formaram um corpo disciplinado e regular.

\section{Considerações Finais}

É importante relembrar que, durante o século XVIII, houve uma intensa mobilização de tropas para o extremo sul da América. As tensões vividas na Europa entre as coroas ibéricas transformaram as capitanias do Brasil Meridional em zona de conflito. A Ilha de Santa Catarina recebeu uma companhia de ordenanças que foi fundamental para o desenvolvimento da capitania. As tropas, assim como em outras capitanias, eram responsáveis pelo desenvolvimento econômico e pela segurança militar.

Sobre as pesquisas no campo militar, Mello (2004, p. 67) menciona que "o interesse pela história militar do Brasil colonial ainda temse mostrado bastante reduzido" e que, quando tratamos das organizações militares de ordenanças e auxiliares, "poucos são os trabalhos dedicados a esse tema na produção historiográfica brasileira", ainda que, lembra a autora, "muito embora elas sejam reconhecidas como instituições de grande relevância na sociedade colonial”. Dessa forma, introdutoriamente tentamos apresentar as condições das tropas de ordenanças relatadas pelos viajantes europeus em passagem pela Ilha durante os séculos XVIII e XIX, além das nomeações realizadas pelos governadores e a dificuldade de organização militar.

\section{Notas}

1 Sobre a constituição histórica de "um espaço catarinense", ver: Martinello, 2016.

2 Mais informações sobre o contrabando na região do Rio da Prata, ver: Canabrava, 1984.

3 Caio Prado Jr. (1953, p. 30) calcula em 3.000.000 de habitantes a população brasileira no dobrar do século XVIII. Duperrey Lesson, navegador francês, quando aportou na Ilha, contabilizou 10.000 pessoas. Em Nossa Senhora do Desterro, capital da capitania, existiam, segundo o navegador, 6.000 indivíduos, essas “[...] distinguem-se em três classes de habitantes, os brancos, os mulatos e os negros; a última é quase em sua totalidade composta de escravos" escreveu Lesson em seu diário (HARO, 1996, p. 268).

4 Sobre o certo à Colônia do Sacramento, ver: Possamai, 2004.

5 Jurisdição Administrativa.

6 Para maiores informações, ver: Sodré, 1979, p. 3031; Putoni, 2004, p. 44-45; Izecksohn, 2014, p. 487. Caio Prado Jr. (1953, p. 322, 325-326) foi o primeiro pesquisador a identificar nas ordenanças uma instituição capaz de aglutinar a "ordem legal" em favor do "auxílio da administração" colonial. Vale lembrar que em Portugal ocorreu um processo de "aversão" ao serviço das ordenanças. Mais informações em, Costa, 2003, 2010.

7 Nelson Werneck Sodré (1979, p. 20) lembra que as instruções dadas a Tomé de Souza, além de fazer "guerra a quem quer vos resistir", o regimento do governador-geral do Brasil devia "para defesa das fortalezas e povoações das ditas terras do Brasil", que todo morador "que nela 
tiver casas, terras, ou águas, ou navio, terá ao menos bestas, espingardas, espada, lança ou chuça”.

\section{Referências}

ANSON, George. "A Voyage round the World". In: HARO, Martim Afonso de Palma de. Ilha de Santa Catarina: relatos de viajantes estrangeiros nos séculos XVIII e XIX. Florianópolis: UFSC/ Lunardelli, 1996.

ASSIS, Edvaldo de. Cuiabá colonial: povoamento e sociedade. Cuiabá: editora Barros, 1988.

Bicentenário da transferência da capital do estado do Brasil da cidade do Salvador para a cidade do Rio de Janeiro, correspondência do Conde de Azambuja e marquês do Lavradio, carta do marquês do Lavradio ao conde de Oeiras, Rio de Janeiro, 20 de fevereiro de 1770. Revista do Instituto Histórico e Geográfico Brasileiro. Rio de Janeiro, volume 255, p. 191-203, abr/jun., 1962.

BRAUDEL, Fernand. O mediterrâneo e o mundo mediterrâneo na época de Felipe II. São Paulo: Martins Fontes, 1983.

BRITO, Paulo José Miguel de. Memória política sobre a capitania de Santa Catharina. Lisboa: Typografia da Academia Real das Sciencias, 1829.

CABRAL, Oswaldo Rodrigues. As defesas da Ilha de Santa Catarina no Brasil: Colônia. Rio de Janeiro: Conselho Federativo de Cultura, 1972.

CANABRAVA, Alice Piffer. O comércio português no Rio da Prata, 1580-1640. São Paulo: Editora da Universidade de São Paulo, 1984.

CARNEIRO, Henrique. Guerra dos Trinta Anos. In: MAGNOLI, Demétrio (Org). História das guerras. 5 ed. São Paulo: Contexto, 2011, p. 163-187.

CARTA DO VICE-REI, Luiz de Vasconcellos e Souza, ao ministro e secretário de Estado dos Negócios do Reino, Martinho de Mello e Castro. Rio de Janeiro, 23 de setembro de 1779. Bicentenário da transferência da capital do estado do Brasil, da cidade do Salvador para a cidade do Rio de Janeiro. Revista do Instituto Histórico e Geográfico Brasileiro. Rio de Janeiro, volume 256, jul/set., 1962, p. 167-170.

CARTA DO MARQUÊS do Lavradio ao conde de Oeiras, Rio de Janeiro, 20 de fevereiro de 1770. Revista do Instituto Histórico e Geográfico Brasileiro. Rio de Janeiro, volume 256, p. 191-203, p. 198, 1962.

COELHO, Manoel Joaquim d'Almeida. Memoria histórica da província de Santa Catharina. Desterro: Typ. Desterrense de J. J. Lopes, 1856.

COSTA, Fernando Dores. Recrutamento. In: Nova História Militar de Portugal. Lisboa: Círculo de Leitores, 2003, 2v. p. 68-101.

Insubmissão: Aversão ao serviço militar no Portugal do século XVIII. Lisboa: Imprensa de Ciências Sociais, 2010.

COUTO, Jorge. A construção do Brasil: Ameríndios, Portugueses e Africanos, do início do povoamento a finais de Quinhentos. Lisboa: Edições Cosmos, 1998.

EXTRACTO do Volume 4 fol. 90 das viagens de La Perouse no ancoradouro desde o dia seis até o dia dezanove de Novembro de mil setecentos oitenta e cinco. Revista Trimensal do Instituto Histórico, Geographico e Ethnographico do Brasil. Rio de Janeiro: Tipografia do Brazil, 1902, tomo LXV, primeira parte, p. 322-326.

FLORES, Maria Bernardete Ramos. Os espanhóis conquistam a Ilha de Santa Catarina, 1777. Florianópolis: Ediufsc, 2004.

FRÉZIER, Amédée F. "Descrição da Ilha de Santa Catarina”. In: HARO, Martim Afonso Palma de. Ilha de Santa Catarina: Relatos de viajantes estrangeiros nos séculos XVIII e XIX. $4^{\mathrm{a}}$ ed. Florianópolis: UFSC/ Lunardelli, 1996.

IZECKSOHN, Vitor. Ordenanças, tropas de linha e auxiliares: mapeando os espaços militares lusobrasileiros. In: FRAGOSO, João Luís Ribeiro; 
GOUVÊA, Maria de Fátima (Org). O Brasil colonial. volume 3 (ca. 1720-ca.1821). Rio de Janeiro: Civilização Brasileira, 2014, p. 483-522.

KEEGAN, John. Uma história da guerra. Tradução de Pedro Maia Soares. São Paulo: Companhia das Letras, 1995.

MARTINELLO, André Souza. Geografia Histórica, discursos espaciais e construção territorial de Santa Catarina. 2016. 245 f. Tese (Doutorado em Geografia Humana) - Programa de Pós-Graduação em Geografia Humana, Universidade Federal de São Paulo, São Paulo, 2016.

MELlO, Christiane Figueiredo Pagano de. A guerra e o pacto: a política de intensa mobilização militar nas Minas Gerais. In: CASTRO, Celso; IZECKSOHN, Vitor; KRAAY, Hendrik. Nova história militar brasileira. Rio de Janeiro: editora FGV, 2004. p. 67-86.

Forças militares no Brasil colonial. Rio de Janeiro: e-paper, 2009.

OLIVAL, Fernanda. As ordens militares e o Estado moderno: Honra, mercê e venalidade em Portugal (1641-1789). Lisboa: Estar, 2001.

PERNETTY, Antoine Joseph. "Histoire D'un Voyage aux Isles Malouines, Fait en 1763 \& 1764; avec des observations sur le Detroit de Magellan, et sur les Patagons". In: HARO, Martim Afonso de Palma de. Ilha de Santa Catarina: relatos de viajantes estrangeiros nos séculos XVIII e XIX. Florianópolis: UFSC/Lunardelli, 1996.

PIAZZA, Walter F. Santa Catarina: sua história. Florianópolis: Edufsc, Lunardelli, 1983.

POSSAMAI, Paulo César. O recrutamento militar na América Portuguesa, o esforço conjunto para a defesa da Colônia do Sacramento (1735-1737). Revista Histórica, São Paulo, n. 151, pp. 151-180, $2^{\circ}$ sem. 2004.
PRADO JR, Caio. Formação do Brasil contemporâneo: colônia. 2ed. São Paulo: Editora Brasiliense, 1953.

PUNTONI, Pedro. A arte da guerra no Brasil, tecnologia e estratégia militar na expansão da fronteira da América Portuguesa (1550-1700). In: CASTRO, Celso; IZECKSOHN, Vitor; KRAAY, Hendrik. Nova história militar brasileira. Rio de Janeiro: Editora FGV, 2004. p. 43-66.

RODRIGUES, José Damião. Da periferia insular às fronteiras do império: colonos e recrutas dos Açores no povoamento da América. Anos 90, Porto Alegre, v. 17, n. 32, p. 17-43, dez. 2010.

SODRÉ, Nelson Werneck. A história militar do Brasil. Rio de Janeiro: Civilização Brasileira, 1979.

SALOMON, Marlon. O saber do espaço, ensaio sobre a geografização do espaço em Santa Catarina no século XIX. 2002. 209 f. Tese (Doutorado em História e Cultura) Programa de Pós-Graduação em Geografia Humana, Universidade Federal de Santa Catarina, 2002.

O exílio da desordem e a segurança da Ilha de Santa Catarina no século XVIII. In: BRANCHER, Ana, AREND, Silvia Maria Fávero (Org). História de Santa Catarina: séculos XVI a XIX. Florianópolis: Editora da UFSC, 2004. p. 79-92.

SILVA, Augusto da. A Ilha de Santa Catarina e sua terra firme: Estudos sobre o governo de uma capitania subalterna (1738-1807). 2008. 300 f. Tese (Doutorado em História Econômica) - Programa de Pós-Graduação em Geografia Humana, Universidade Federal São Paulo, 2008.

TEJERINA, Marcela Viviana. Los portugueses en el comercio y la navegación rio-platenses. In: SILVA, Hernán Asdrúbal (Dir.). Los caminos del Mercosur - historia económica regional, etapa colonial, Mexico (DF). Instituto Panamericano de Geografia e Historia, 2004. p. 91-120. 